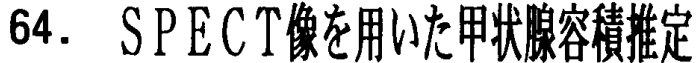

Estimation of thyroid volume using SPECT images

\section{帝京大学医学部附属市原病院 放射線部}

○伊場 昭三 二見 務 大曾根 文雄

Shozo Iba Tsutomu Futami Fumio Ohsone

[目 的] 人体哭器の大きさを非侵警的に知ることは，飭床医学において重要である。今回甲状腺 疾患の診断に T 1 - 201，T c - 9 9 m検査した患者のS P E C T像とX湶CT像から甲状腺容積 を求めることが可能であるかを,ファントムと峦症例で検討をした。

[方 法] 甲状腺の容積を求めるための基碳的な榆討を, 䫓部ファントムの甲状腺部に 5 種類の容 積のファントムに, T 1 - 201 , T c - 99 mを入れる。撮像したファントムのS P E C T像の中 の最大カウントを基準とした\% R O I を S P E C T像に作成をおこない，RO I 内の総ピクセル数か ら容積を求めた。又, プラナー像と造影 C T 像M R 像の断層像にR O I を, 作成して求めた容積を S P E C T 像で求めた容積と比较を行なった。

[装置と条件］SPECT装置 日立RC-150 D T 画像处理装置 HARP-100 X線 $\mathrm{CT}$ 日立C T-W600 $\mathrm{CT}-\mathrm{W} 2000$ 撮像条件 $360^{\circ} 64$ ステップ 1 ステップ 2 0 マ秒 マトックス $64 \times 64$ フィルタ バターワース ラマチャンドラン 患者の撮像はT 1 - 20101 T c - 99 mを静注 5 分後からS P E C T 取集を行なった。

[結 果] S P E C T 像から甲状腺容積を求めるのに, $74 \mathrm{k} \mathrm{B} \mathrm{q} / \mathrm{m} 1$ のR I 溶液を入れた甲状 腺ファントム $20 \mathrm{c} \mathrm{m}^{3}$ で収集条件を調べた結果が図 $1 \mathrm{~A}$ である。 $20 \mathrm{c} \mathrm{m}^{3}$ のファントム容積を得 るS P E C T像の収集は，1ステップ 15 秒以上が必要であった。図 1 B は 1 ステップ 10 秒で画像 収集したときに必要とするR I 泣度を求めた結果である。0.37 MB q/m 1 以下であると S P E C T 像から容積は求められない。甲状腺ファントムのS P E C T像の全スライスの中の最大カウント を 100 に基潐した c u t o f f \% RO I から，甲状腺容積を求めた\% RO I は T 1 像が $53 \%$, T c 像は $50 \%$ \%ファントム容積に近倾した。

X線 C T 像に作成したROI 内のピクセル数から求めた容積はファントム容積より小さかった。図 2 はT 1-201 $740 \mathrm{MB} \mathrm{q} \quad \mathrm{T} \mathrm{c}-99 \mathrm{~m} \quad 185 \mathrm{MB} \mathrm{q}$ を静注した患者のS P E C T像の\% RO I のピクセル数で求めた結果と，X線 C T 像MR像のRO I で求めた容積を比较した結果である。

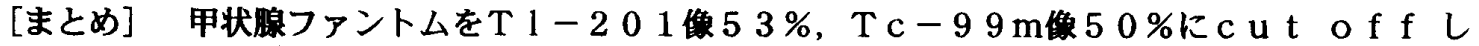

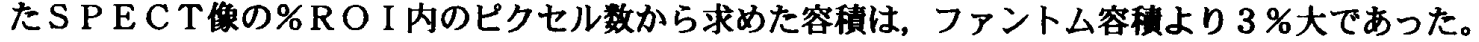

X線 C T 像に作成したRO I 内のビクセル数で求めた容積は，3．3\%低值であった。プラナー像 の大きさから計算した甲状腺容積は，S P E C T 像から求めた甲状腺容積より $37 \%$ 小さい值となつ た。

図 1

Measurement of Thyroid Volume by SPECT

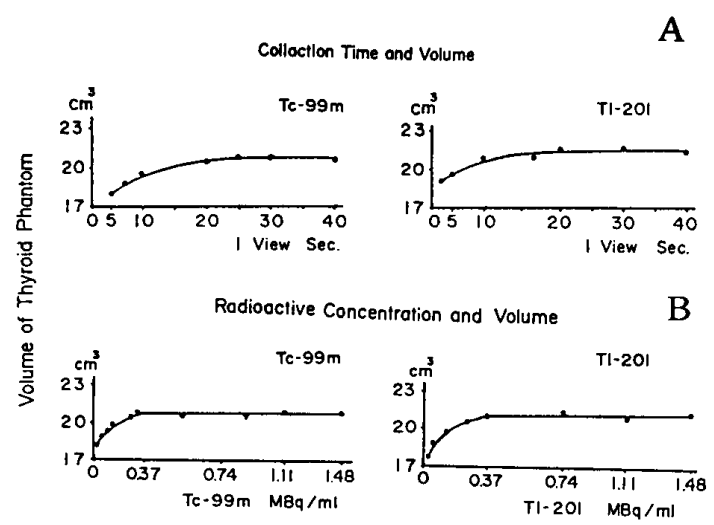

図 2

Comparision of Thyroid Volume

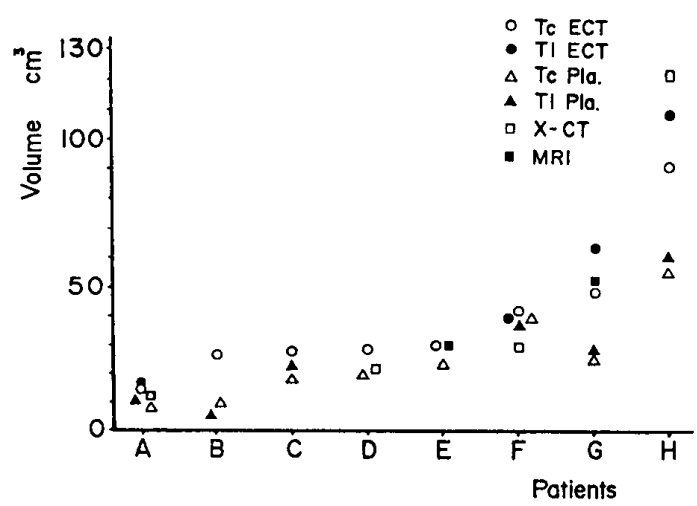

